\title{
Forthcoming evidence-based courses and conferences
}

\section{3}

\section{September}

EQUATOR Workshop for editors and peer reviewers

Swissotel, Chicago

Further information is available at

http://www.equator-network.org/courses-events/2013-annuallecture--workshop/\#PRCworkshop

\section{September}

EQUATOR Lecture

Swissotel, Chicago

Further information is available at

http://www.equator-network.org/courses-events/2013-annuallecture--workshop/\#PRCLecture

\section{9-13 September}

$19^{\text {th }}$ Oxford Workshop in teaching Evidence-based Practice

St Hugh's College, Oxford

Further information is available at

http://www.cebm.net/index.aspx?o=7801

\section{9-23 September}

$21^{\text {st }}$ Cochrane Colloquium, Quebec

Further information available at

http://colloquium.cochrane.org/

\section{5-9 October}

ADA/Forsyth Course on Evidence-Based Dentistry

The Forsyth Institute, Cambridge, MA

\section{October - 2 November}

EBHC International Joint Conference Evidence, Governance, Performance

Taormina (Italy)

Further information is available at

www.ebhc.org

\section{7-29 November}

The Critical Appraisal Skills Programme (CASP) UK 3 Day: Introduction to Critical Appraisal \& Train the Trainer Event Kellogg College, Oxford

Further information is available at

http://www.casp-uk.net/casp-uk-training-week/

\section{4}

\section{9-23 May}

CASP International Training week

Kellogg College, Oxford

Further information is available at

http://www.casp-uk.net/wp-content/uploads/2011/11/CASP-

Training-WeekTryptic-May-2014-3.pdf

\section{Cochrane Workshops}

Details of workshops organised by the Cochrane Collaboration in a range of locations across the world are listed on the web at http:// www.cochrane.org/tags/news-events/workshops

\section{Oxford International Programme in Evidence-based Health Care, MSc in Evidence-based Health Care}

This is a joint programme from Oxford University's Continuing Professional Development Centre and Department of Primary Health Care. It is offered as a part-time course consisting of six taught modules and a dissertation. The flexible structure of the course has been devised to fit with the structure of specialist training and to accommodate student choice. The modules from the International Programme in Evidence-based Health Care can be taken as stand-alone short courses.

Available modules are:

- The Practice of Evidence-based Health Care (compulsory for MSc)

- Introduction to Study Design and Research Methods (compulsory for MSc)

- Clinical Epidemiology and Decision Making (Evidence in Practice)

- Ethics in Health Care

- Evidence-based Change

- Evidence-based Dentistry

- Evidence-based Diagnosis and Screening

- Further Practical Statistics

- Patient-based Evidence

- Qualitative Research Methods

- Randomised Controlled Trials

- Statistics for Health Researchers (online)

- Systematic Reviews.

For further information visit the website at http://www.conted. ox.ac.uk/courses/professional/staticdetails.php? course $=210$

\section{MSc in Evidence for Public Policy and Practice}

Evidence for Policy and Practice Information and Co-ordinating (EPPI) Centre, Social Science Research Unit, Institute of Education, London

This MSc has been designed for graduates and policy-makers, practitioners, managers and researchers who want to become more skilled in systematic reviewing and develop a critical understanding of the relationships between research evidence and public policy and practice. Students will be encouraged to build their studies around their own areas of interest. These could relate to social welfare, education, crime and justice, transport, health and health promotion, housing or any other area of social policy or practice. This degree can be completed in one year full-time or over two years part-time. Core course modules are delivered in four full-day sessions, one week apart. These modules can be taken as short courses without accreditation.

Further information: please visit our website (http://eppi.ioe. ac.uk/cms/Default.aspx?tabid=168)

If you have an evidence-based dentistry event or workshop you would like to include here, please contact us at ebdeditor@nature.com 